\title{
7. The Tikkun Indigenous Youth Project: A Land-based Well-being Retreat by Youth, with Youth, for Youth
}

LISA KORTEWEG, JACKY CHAN, AND KYLEE JOHNSTONE

\section{Abstract}

Lakehead University's Tikkun Indigenous Youth Project in northern Ontario/ Canada was a collaborative Indigenous youth leadership, community engagement, and well-being project that was designed to support Indigenous students who have to leave their northern home communities to pursue secondary schooling in Thunder Bay - a challenging, difficult, and risky journey for many. Through our collaborative research with high schools, youth role-models, and educators, we were able to provide the conditions whereby Indigenous youth gained opportunities to meet and gain strength with their Indigenous peers in culturally-focused activities, share stories in a holistic circle, and develop leadership skills while engaging in well-being practices and self-determining needs and actions. We ran the Indigenous Tikkun Youth Project to carve out action sites where young people from systemically oppressed and marginalized communities could self-determine their needs and actively contribute to collective healing, repair, and change through civic engagement in their school communities. We designed weekly Indigenous youth drop-in sessions, a leaders-intraining (LiT) program for self-selected Indigenous students, and our culminating Land-based well-being outdoor camp retreat. This chapter details the philosophy and purpose of the culminating Land-based wellbeing retreat, the Land-based outdoor leadership camp processes, the Leaders-in-Training strengths-based activities, and the responses of the youth participants, all decided, led, and engaged in by Indigenous youth, for Indigenous youth, and with Indigenous youth. 


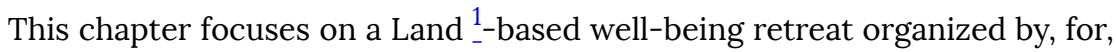
and with Nishnawbe ${ }_{-}^{2}$ youth in Thunder Bay, Ontario, as the culminating event of the Indigenous ${ }_{-}^{3}$ Tikkun Youth Project. Lakehead University's Tikkun Indigenous Youth Project was designed to provide a culturally safe (Cooke, 2018; Hare \& Pidgeon, 2011), holistically healing (Castellano, 2006; First Nations Health Authority, 2015; First Nations Information Governance Centre, 2014), and open/welcoming space (Korteweg \& Bissell, 2016) where Indigenous youth would be able to decide by/for/with themselves what civic or community engagement means to them as Indigenous youth in Canada. Civic education was reconceptualized as a space for Indigenous youth to decide what actions they wanted to claim in order to start decolonizing education at this critical time of Canada's post-Truth and Reconciliation Commission (TRC) era.

We felt compelled to try and improve Indigenous civic engagement education as we were already involved with many Indigenous education projects and knew how difficult and colonial education systems were for Indigenous youth across Canada. As stated in their own words, the Indigenous youth writers of the Feathers of Hope report (Provincial Advocate for Children \& Youth, 2014) had many testimonials of how devastating and damaging colonialism has been on Indigenous communities and Indigenous youth's futures:

With these deeply internalized negative beliefs we carry within ourselves, how can we be expected to feel confident enough to be able to achieve the dreams we had as small children, before the shabby reality of our life situations set in? (Provincial Advocate for Children \& Youth, 2014, p. 70)

We felt compelled as education researchers to address the role of education, specifically civic engagement education, in this era of the post Truth \& Reconciliation Commission's (2015) Calls to Action for educators (\#62 and \#63). However, we also knew that seeking civic engagement education with/ by/for Indigenous youth as non-Indigenous settler-researchers does not come without many complexities and difficult implications. As described by Korteweg and Bissell (2016),

[I]t is highly problematic to design and implement a research project 
whose primary goal is to support civic engagement when Indigenous youth have been told and taught, [explicitly or implicitly,] that their communities, systems of government, Elders as wisdom leaders, languages, laws and protocols are all at a deficit to Western models of citizenship. (p. 19)

The Lakehead University Tikkun site is located in Thunder Bay and focused on northern ${ }^{4}$ Nishnawbe youth who have no choice but to leave their communities and families in the Far North of Ontario in order to "get an education" in this city's high schools. "Getting an education" has become, for many northern students, a short-hand expression for a rite of passage of life in the city. This passage either results in the successful completion of secondary school before the age of 20 , dropping out, or being "forced out" (Tuck, 2011) by racism and extreme alienation, thus causing the youth to return home to their northern community without many options for an education, a job, or a promising future. Thunder Bay has long been a critical case study of the continuing colonialism and inequities against Indigenous youth in Canadian education systems that reproduce oppression and systemic racism (Hare \& Pidgeon, 2011); dysfunctional bureaucracies that govern daily life and needs of housing, food insecurity, chronic poverty, and lack of access to basic services such as dental and healthcare (Macdonald, 2017; Talaga, 2017); and desperate mental health conditions of illnesses, homesickness, loneliness, and social alienation that are real and compounding for many northern Indigenous youth (Gardam \& Giles, 2016).

We primarily focused on serving northern, Nishnawbe youth who have no choice but to leave their communities and families in order to "get an education" in urban (provincial) high schools, a phenomenon that impacts most First Nations communities across Canada. This risky predicament continues because most northern or rural First Nations, such as those in the Nishnawbe Aski Nation (NAN) territories, do not have the federal funding or capacity to run their own on-reserve community-based high schools (Parriag, Chaulk, Wright, \& MacDonald, 2011), which means that most Nishnawbe Indigenous youth have to leave their homes to pursue secondary education in towns and cities (Richards, 2014). Indigenous youth's dislocation from their communities then subjects them to multiple risks, harms, and dangers: institutionalized racism in schools, Eurocentric cognitive imperialism in the curriculum (Battiste, 2013), teacher deficit perceptions of academic abilities, psychological isolation in alienating classrooms, and 
racist abuse or physical aggression on the bus, streets, or school hallways (Richards, 2014; Talaga, 2017). These unsafe conditions can all lead to serious educational disengagement or being forced out from achieving a high school diploma, resulting in a significant loss of talent, ability, and hope (Neeganagwedgin, 2013; Tuck, 2011).

From 2000 to 2011, seven NAN youth, now referred to as the "Seven Fallen Feathers" (Talaga, 2017), flew hundreds of kilometers away from their communities and families and died while attending school in Thunder Bay. The youths' untimely deaths led to the longest Ontario coroner's inquest where "three of the five river deaths could not be explained" (Macdonald, 2017, para. 37) and from which a list of 200 recommendations were made to all municipal institutions and services that failed in their duty to protect the city's most vulnerable, Indigenous students. These unresolved deaths continue to increase the racial tensions and gulf of misunderstandings between non-Indigenous settler-residents and Indigenous peoples. The deaths also instill fear and mistrust of schools for the physical, mental, and cultural safety of Indigenous youth (Macdonald, 2017; Talaga, 2017). We believe Thunder Bay is the bellwether for the educational challenges, risks, and dangers that many Indigenous students face in urban centres and towns across Canada (see Talaga's Massey Lectures, 2018). Thunder Bay is also a prime site for teachers and educators' civic responsibilities in reconciliationas-education (Korteweg \& Fiddler, 2018). We follow Senator Murray Sinclair's wise counsel (Sinclair, 2015) that reconciliation by Canadian settler society has to start and be driven by teachers and education systems; educators, curriculum and pedagogies have to proactively acknowledge and repair the damages and injustices instilled by the Indian Residential School (IRS) system that continue to harm Indigenous youth and communities and perpetuate neo-colonialism in mainstream schools.

In this chapter, we present our Tikkun Youth Project contribution of a model that includes a Land-based well-being retreat that was designed and implemented by Nishnawbe youth, with Nishnawbe youth, and for a collective gathering of youth strengths and healing while "getting an education" in the city of Thunder Bay. We outline the key components of this retreat's design, including a youth-to-youth mentorship process and youthled activities that create a culturally safe space for positive engagement with peers and create the conditions for youth to decide by/for themselves as a community what they want for collective strength and civic engagement. We conclude the chapter by providing recommendations for educators, 
community organizers, and school equity activists on how to co-design and facilitate a Land-based well-being retreat by and with youth to support the self- and collective-determination of marginalized students who continue to face serious risks and barriers in their rights to "get an education."

\section{Year Three of the Lakehead University Tikkun Indigenous Youth Project}

In the third and final year of the Tikkun Indigenous Youth Project, we focused on one urban high school (provincial jurisdiction) and their FourDirections Program for northern Indigenous youth - a program focused on keeping students in school and experiencing incremental success, along with ongoing counselling and holistic supports from a graduation coach and an Indigenous achievement tutor. The goal of the third and final year (2015-16) was to synthesize and put into action the observations and research findings from the four high school sites and Indigenous youth groups that were the focus of years 1 and 2 (2013-2015). For the last culminating project, we chose the most opportune high school (out of the original four) for a more intensive project than the weekly drop-in lunch hour sessions of informal well-being games, activities, and sharing circles. It was only in the last phase of the Tikkun Youth Project that we believed that we had acquired adequate information on how to assist the Indigenous youth to drive the collaborative research project with peers and to ensure cultural safety, authentic and good relationships, and willing administrative and teacher partners at the school and school board. We decided upon the urban high school that had started its own Indigenous-focused Four-Directions Program as the best site to focus on well-being approaches that would support Indigenous youth engagement, self-determined advocacy, and building of cultural and leadership strengths to do this work by youth, for youth (Korteweg \& Bissell, 2016).

To focus our project efforts on this one group of Indigenous youth, we visited the high school every week to build stronger relationships with the regular drop-in group of Indigenous youth as well as develop collaborative partnerships with the high school's Indigenous Graduation Coach of the Four Directions Program in addition to the First Nation, Métis, and Inuit (FNMI) Achievement Tutor. These two educators were critical for maintaining 
support for the Indigenous youth leaders-in-training (LiTs) as well as keeping the continuity of the project.

Our Tikkun Indigenous Youth Project sessions were held in the nish (short for Nishnawbe or Ojibwe) room - a safe space for Indigenous youth to use during school hours under the supervision of the FNMI Achievement Tutor. Any Indigenous student was welcome to the weekly lunch-hour sessions, and all Indigenous youth were strongly encouraged to join our project sessions by these two educators and other school staff. The Tikkun research team did not miss a single week unless there was a field trip scheduled or a snow day. It is critically important to be present, reliable, and committed to these youth when there can be much chaos or strained relationships in their school lives while living far away from home, often residing in boarding homes and facing challenging racism in the city.

During the Fall term, as the lead researcher or principal investigator (PI) of the Lakehead University Tikkun Indigenous Youth Project, Lisa identified and recruited four outdoor-experiential specialist teacher-candidates (TCs) from her unique Indigenous education course (ED4000), Indigenizing Perspectives and Practices in Education (IPPE), an intensive honours course in which Jacky was the Graduate teaching Assistant (GA), as well as the research assistant (RA) of the Lakehead Tikkun Indigenous Youth Project and second author of this paper. The four TCs had been explicitly prepared and taught in ED4000-IPPE on how to build authentic and strengths-based intercultural relationships with First Nations students from their multiple cultural immersion assignments and experiential learning requirements of the specialized Indigenous education course (see Korteweg \& Fiddler, 2018). We were fortunate to have these non-Indigenous preservice teacher rolemodels ( 23-24 years old) act as youth mentors and join the weekly lunchhour sessions to encourage, support, and amplify a collective well-being through positive play-based games, team initiatives, and sharing circle discussions with the Indigenous youth.

After four months of these weekly drop-in sessions at the designated high school, the Tikkun team (Lisa-PI, Jacky-RA, and the four TCs) began collaborating with four northern Nishnawbe students as youth leaders who had been selected by our school collaborators - the Indigenous Graduation Coach and the FNMI Achievement Tutor. Once we had our Indigenous youth leaders (in training), we were then able to move towards a youth-driven and youth-designed well-being retreat. An invitation to attend an early spring retreat at the school board's outdoor education centre was sent out to 
all the northern Nishnawbe students at the high school. As the planning progressed and the retreat dates neared, we had close to 20 Indigenous northern youth registered, along with six educators from the school and school board. All school staff attendees were familiar with the Indigenous youth but our two project collaborators, the FNMI Achievement Tutor, and the Indigenous Graduation Coach had the strongest and most important relationships of trust with the Indigenous youth and were the main reason why the youth wanted to participate.

The retreat was Land-based, experiential, and focused on well-being in order to achieve the goals of the Tikkun Youth Project: to repair the deficits and damages of systemic oppression in schools against marginalized youth, and to shift education towards reconciliation by youth determining and leading the changes that they want to see in their communities and schools. With the Lakehead University's Tikkun Indigenous Youth Project, our goals were to 1) to build opportunities for advocacy and self-determined strengths through positive relational experiences amongst the Nishnawbe youth; 2) to provide culturally safe spaces in a historically colonial institution (education) in which Indigenous youth could voice their stories and concerns while being heard and affirmed by other youth; and, 3) to empower all the participating Indigenous youth to become agents of resurgence by building confidence, pride, collective strength, and community amongst themselves during this retreat.

\section{Design of the Tikkun Land-Based Well-being Retreat}

The design of the Tikkun Indigenous Youth well-being retreat began with Jacky's accumulated experience with a volunteer-driven Canadian not-forprofit organization, Zen's Outdoor Leadership Camps for Youth (ZOLCY), that worked globally with marginalized youth in underserved communities of Jamaica and Nepal. ZOLCY's mission was to cultivate positive well-being through a variety of means: youth leadership development in the marginalized communities, service learning for cultural immersion and global perspectives by White Canadian university students, intercultural group bonding through Laughter Yoga, team-building initiatives, and wellbeing games. The Tikkun retreat design was based upon Jacky's refined 
approach from delivering a dozen 4-day camps with seriously poor and marginalized youth in Riverton, Jamaica.

Riverton is one of Kingston, Jamaica's designated land-fill sites while at the same time a residential community for hundreds of chronically impoverished families. The Jamaican youth in the ZOLCY camps came from situations of severe socio-economic, physical, emotional, and spiritual distress similar to that of many Nishnawbe youth from northern communities in Ontario who live without access to basic human rights to clean water, adequate housing, continuous electricity, or quality health and education services. Jacky's experience of designing the ZOLCY camps provided the basic framework of activities for the Tikkun retreat of Laughter Yoga, team-work challenges, and play-based socializing and interactions with peers. Laughter Yoga was employed as an embodied somatic method for the release of emotional blocks, negative self-talk hindrances, or social impasses, while the teamwork gave the youth a focus and purpose to make peer connections and creatively problem-solve challenges together. The third key component was play-based activities for fun, positive, and holistic engagement with peers that we knew students were not experiencing in their school or urban lives. We reasoned that the tested and reiterative approach of the ZOLCY's youth camps would be a very relevant and foundational design for the culminating retreat of the Tikkun Indigenous Youth Project.

\section{The Tikkun Indigenous Youth Land-based Retreat}

The focus of the Tikkun Indigenous Youth Land-based retreat was to build positive healing relationships with youth and by youth. All the retreat activities were designed to provide a culturally safe and decolonized space for Indigenous youth to develop a voice for self-advocacy; to empower youth participants to become leaders and agents of change; and, to foster a collective spirit for relationship building or bonding, thus gathering strength as a community of northern Nishnawbe and instilling pride and confidence in their identities while away from their First Nation communities and in the city seeking an education. Healing from colonial harms was promoted through a Land-based location in the bush at an outdoor centre, and through cooperative games, team challenges requiring problem-solving and a collective effort, Laughter Yoga (LY) to release stressful emotions, and 
sharing circles to process experiences and share stories of life in the city and at school.

In this section, we describe key components of the retreat that were successful for the Indigenous youth's gathering of positive strength and cultural bonding. These components included the following: 1) a mentorship process of youth working with youth where youth leader-mentors work in partnership with youth Leaders-in-Training (LiTs); 2) the fun "back-pocket" games or positive icebreakers to break down social isolation, awkwardness, or alienation; 3) team initiatives or challenges that would focus the purpose of coming together; 4) sharing circles to share stories, emotional experiences, and process collectively; 5) Laughter Yoga to release dis/stress from "getting an education in the city" along with emotional blocks of anxiety and depression; and 6) drama-based role-plays of risks and challenges that many Indigenous youth face while attending school in Thunder Bay.

The mentorship process. Cooke (2018) states that emotionally strong and healthy people are those who have a high level of well-being linked to self-determination or the autonomy to make decisions that affect one's livelihood. When many northern Nishnawbe youth have little choice but to move to Thunder Bay to "get an education," hundreds of kilometres away from their home communities, then these youth are already in a position of subjugation with a reduced agency over their rights, their autonomy, and their self-determination for future opportunities. Our Tikkun approach to wellness and well-being were closely aligned to Cooke's (2018) philosophy of self-determination for mental health when the Nishnawbe youth were given the freedom and opportunity to take the lead and choose what they wanted to do in terms of activities on the Land during the retreat. It was a brief respite of decolonized and Indigenous majority space for these northern Nishnawbe students while also an actualization of the Tikkun research findings implemented into good practice by/with these youth.

We developed the ZOLCY mentorship program to focus on the four Nishnawbe LiT youth who then demonstrated leadership and selfdetermination with their Indigenous peers. During an evening sharing circle, one of the youth leaders (LiTs) expressed to their peers that they were motivated to attend the retreat due to the opportunity to engage in leadership: "I thought that I got what it is to be a good role model ... I've got to be a leader for some reason ..." (Cabin 1, 38:3).

To encourage Indigenous youth civic engagement through selfdetermined leadership, Jacky first modified the LiT mentorship program by 
focusing on three objectives that the Nishnawbe youth would be able to respond to: 1) tailoring the goals and objectives of the Tikkun Youth Project to be aligned to Indigenous perspectives; 2) reworking team initiatives for a northern Ontario Land-based context; and 3) learning how to facilitate groups of school peers from different First Nations communities but all together in the city. We focused on these skills and capacities with the four Indigenous youth LiTs and their four teacher-candidate partners or paired mentors. Each pair of Indigenous youth LiT and non-Indigenous TC worked well together to learn how to facilitate games, direct initiatives, and guide sharing-circles. The purpose of the pairing of youth-mentor with youth LiT was to help build a cohesive relationship and support system for running all the activities and encouraging peer-to-peer participation.

During the six weeks of intensive training, the pairs learned how to coteach and facilitate games and team initiatives, figuring out the logistics of the retreat along with their roles and responsibilities. The primary focus of this training was to support and strengthen the youth LiTs' confidence and leadership capacity through play-based training in order to then encourage their peers (while empowering themselves) towards embodied healing through self-determination. The role of the teacher-candidate mentors was to focus their support on their LiT mentee in order to build the youth's capacity to lead the whole group through games or initiatives and to facilitate sharing circles in their cabin each night of the retreat.

Back-pocket games/icebreakers. These activities are purposefully simple games that do not require complicated rules or equipment. The term "backpocket" refers to the idea that these games can be "pulled out" whenever the need arises for a group to come together and where no complicated planning or complex materials are needed. The only requirement is participants who are willing to play. The main objectives of these games are to facilitate playful interactions amongst participants in order to create a fun, cohesive, and safe environment while "breaking the ice" or any social awkwardness or impasses. An example of a back-pocket game is Rock, Paper, Scissors where rules are flexible, and the only requirement is two participants.

We first introduced these games during the informal drop-in lunch sessions at the school by encouraging the youth to participate by watching Jacky and the TC mentors enthusiastically play. Sometimes, the youth would not pay attention or would try their best to remain disengaged to appear "cool" in the school context. But, with our regular lunch-hour visits, more often than not, the youth would be compelled to look up from their cell 
phones and find the spectacle of the game hilarious or infectious. As the youth became comfortable with our presence in their culture room and more accustomed to these silly and fun games, more youth would stand up and initiate their own participation. These games were easy to remember and to lead, always ended in laughter, and became the retreat's favourite pastime as the Nishnawbe youth leaders (LiTs) took the initiative to start games on their own with their peers while waiting for meals or during blocks of free time. These games started a natural process of self-initiation and selfdetermination that extended to asking for and maintaining an outdoor fire in the designated fire pit during the evenings and mornings to sing traditional songs and engage in ceremony together. When given the decolonized space in an Indigenous-focused Land-based setting, these youth knew what they needed to come together, share, and heal.

Team initiatives. These activities were co-operative activities that challenged participants to work and problem-solve together through peerto-peer interactions and group efforts. Similar to back-pocket games, team initiatives were also not resource intensive; however, the youth were more invested as they challenged groups of participants to think, communicate, problem-solve, and trust each other to work together towards a common goal. An example of a team initiative that we used during the retreat was the Flip the Tarp challenge. A group of youth is directed to stand on a tarp and then instructed that the objective is to flip the tarp over (as a group) without anyone stepping off the tarp. The goal of any team initiative is to have participants work together to overcome the challenge and to gain a feeling of collective accomplishment and belonging rather than individual failure and isolation - an experience that too many northern Indigenous youth feel and endure multiple times during regular high school classes.

Each team initiative always ended with a debriefing of what went well or what was challenging with the team's work on the initiative. To consolidate the collective effort and spirit of the activity, we prompted the youth with questions such as "How did the group decide on what to do?", "What did you learn from this initiative?", "What is the relevance of this initiative and how can you apply what you learned here to a real life setting, such as school?", "Was there anyone who felt that they were not being heard?", and "What was frustrating and why?" These prompts gave the youth a relevant and authentic situation where they could share their responses and feelings while others were invested, present, and ready to listen.

During the retreat, it was the four Indigenous youth leaders (LiTs) who 
facilitated each initiative in order to give them incremental opportunities to see themselves as leaders, facilitators, or amplifiers with their TC mentors as supportive back-up. Although unsure and uncomfortable with this new approach and leadership responsibility inside the high school context, these four Indigenous youth leaders expressed increasing confidence and excitement and an empowered motivation to facilitate more activities during the Land-based retreat. It was remarkable to witness the growth of these Indigenous youth leaders from being unsure, shy, or withdrawn during the drop-in sessions during the first two years of the Tikkun Youth Project. We observed one youth in particular who did not often engage in activities or conversations at the start of our drop-in sessions; however, during the Landbased retreat, this same youth, now in the position of a leader (LiT) to their peers, had created their own team initiative, regularly engaged in individual and group conversations, and led impromptu back-pocket games with peers. This was a regular occurrence during the Tikkun Indigenous Youth retreat and demonstrates the value of decolonized conditions in education for selfdetermination (Cooke, 2008) and authentic activities where youth can reclaim cultural autonomy, away from colonial settings of mainstream/ whitestream school.

Sharing circles. The activity of sharing or talking circles is an important cultural method used in many First Nations communities to come together, communicate, share, and witness stories with one another. It is an Indigenous-focused communication process that has been used by First Nations health organizations as an effective means to address trauma, to promote the healing process, and to create safe spaces for participants to share stories and express their experiences and emotional responses (Castellano, 2006). During the Tikkun Indigenous Youth retreat, the youth were already organized into four cabin groups where each cabin had one Indigenous youth leader (LiT), their TC mentor-partner, and 3-5 youth peers. At the end of each retreat day, the cabin groups would process the day's activities and emotions with a sharing circle led by the Indigenous youth leader (LiT) and supported by the non-Indigenous TC mentor. Usually the cabin sharing circle would begin with ice-breaker questions, such as, "What was your rose of the day?" and "What was your thorn of the day?" Or, they could start with fun youth-focused questions such as, "If you could have any super-power, what would it be and why?" The purpose of the last question was to help ease any tension or anxiety that might arise if someone had a particularly upsetting "thorn of the day." 
The cabin sharing circle acted as a safe space for the members of each cabin group to be heard and reaffirmed by peers that their voices and experiences mattered. For example, on the second night, several youths began opening up and talking about their experiences of trauma, schoolrelated racism, and the social injustices that they often face while having to live in Thunder Bay to access their right to a high school education. Many Indigenous youth described how they felt Canadian mainstream "society ... put [them] in a box ... [and] gave [them] a label of how you're supposed to act" (Cabin 3,42:85), or how there was never the opportunity in school to "talk about [issues of race] ... [how they were] never ... given the chance" (Cabin 3 , 42:96), and how "it is hard [for Indigenous youth to] come to school because [they] feel like [they] don't belong anywhere" (Youth Leader interview).

The sharing circle was a core indigenized method in the Tikkun Indigenous Youth Land-based well-being retreat where the Nishnawbe youth leaders achieved greater ownership and leadership over the collective sharing process at the end of each day. It was a critical component to allow the northern students to share their own take-away messages and what they learned together in terms of what made them strong together, what they were still struggling with in terms of dealing with the colonial urban education system away from their communities, and their right to determine their own Indigenous identity and practices in this space of the whitestream (Grande, 2008) school board's outdoor education centre. We believe that it was the sharing circles that started a collective cultural process whereby the youth felt safe and encouraged to gather at the outdoor fire pit to sing traditional songs in Anishinaabemowin (Ojibwe language) and perform ceremony in their own way without fear of racist reactions or colonial reprisals. We knew we had achieved a culturally safe space during the retreat that led to the youth gaining greater cohesion in their peer-to-peer relationships and collective healing.

Laughter Yoga. Laughter Yoga is a practice involving prolonged voluntary laughter, comprised of simulated laughter exercises that elicit the physiological and psychological benefits of spontaneous laughter. Laughter Yoga is done in groups, with eye contact, jokes, and playfulness between participants in order to promote reduced stress and increase collective wellbeing. Laughter Yoga was particularly important for this group of Indigenous youth at the retreat because it was an embodied or somatic method that permitted the students' psychological walls and anxieties to break down or release physically during the large group Laughter Yoga session. This 
physical release helped the youth to open themselves up to emotional awareness of their own bodies and to engage themselves more fully with their peers and the participating educators. The session had a strong watershed impact on each individual as well as for the dynamics of the whole group. Many youths commented during the sharing circles on the experience of releasing stress and having new positive energy emerge that literally helped them move forward. One Indigenous youth described their experiences with Laughter Yoga "[As] amazing ... [and that it gave them] a really good release" (Cabin 2, 45:1) while another shared how the positive results had motivated them to want to "do that more often you know ... laughing yoga" (Cabin 2, 45:5). The school staff and TC mentors seemed genuinely surprised at how deeply the Laughter Yoga session impacted the Indigenous youth because most had never seen these Indigenous youth smile, let alone laugh. One youth described the impact the laughter yoga had on their spirit, with "the biggest take away of the day was the laughing ... [and how they] went to the spirit realm ... [and] found [their] inner peace" (Cabin $1,41: 54)$.

\section{Themes and Analysis of the Tikkun Indigenous Youth Project's Land-based Retreat}

The research of the Tikkun Indigenous Youth Project's Land-based retreat was decolonial and Indigenous-focused in its methods and analysis. We collected participant observation qualitative data of the weekly lunch-hour sessions, the plans and activities that changed each week with the Indigenous youth leader (LiT) and TC mentee feedback, and documented each activity of the retreat and audio-taped the cabin sharing circle sessions and youth participant feedback. All data were transcribed and then entered into Atlas.Ti - a qualitative software program - in order to code for crossconversational themes. As transcribers and co-participants in the retreat, we listened carefully to each recorded sharing circle and carefully read and reviewed each transcript to get a sense of the whole retreat's impacts. Atlas as a coding program helped us find similar concepts between the participants' stories and to bring our team members' interpretations together through the refinement of the codes and then themes of interpretation.

175 | The Tikkun Indigenous Youth Project 
Four major themes of meaning-making emerged from the Tikkun Indigenous Youth Project's culminating Tikkun Indigenous Youth retreat: 1) building a collective and cultural awareness as civic or community engagement; 2) raising the strengths and capacities of Indigenous youth through well-being and healing to self-determine their civic engagement; 3) culturally safe and Indigenous respectful school curriculum must be the first step to engage Indigenous youth by reducing or stopping settler-colonial harms; and 4) indigenized or Indigenist civic engagement education is first focused on Indigenous youth self-determination for democratic participation in their education by youth, for youth, with youth, and is good for everyone, including all Canadians.

\section{Building Collective Awareness for Community/Civic Engagement}

When given the opportunity to experience a positive, culturally safe space where questions can be asked and answered in a collective Indigenousfocused setting that encourages cultural and personal expression, the Indigenous youth of Lakehead University's Tikkun Youth Project were able to participate fully in community building for Indigenous youth, by Indigenous youth, and with Indigenous youth as strong civic engagement. As nonIndigenous researchers and educators, we became increasingly convinced and committed to the principle that Indigenous youth must be given the decolonial space and opportunities to self-determine in order to engage in an indigenized model of community/civic engagement education.

During the Land-based retreat research of the cabins' sharing circles, we noted that the Indigenous youth not only participated, but also gained strength in collective awareness, even when it meant that they came to realize how they were being actively subjected to colonial oppression, marginalization, and anti-Indigenous racism in their classrooms, city experiences, and social interactions. We knew that these oppressive conditions were reduced in their damaging effects by the counter approach of the Tikkun Youth Project's drop-in lunch sessions that emphasized positive, authentic, and strengths-based relationships between the youth, the assisting educators, and volunteer TC mentees. Indigenous youth were able to participate for themselves in this participatory action process despite 
ongoing school and city oppressions because they were able to reclaim a certain amount of autonomy through the mentorship/leadership activities along with the conditions for trusting relationships and safe spaces with peers.

The safe space was created by having these sessions in a designated cultural classroom that reflected Indigenous ways of knowing and socializing in a positive framing. The Indigenous cultural room was a school space where the Indigenous youth felt safe and where the youth knew they could find supportive educators - the FNMI achievement tutor and the graduation coach.

This explicit emphasis of cultural safety was extended by the Land-based retreat because it took place outside the high school, outside the city $(20 \mathrm{~km}$ northeast of city limits), in the bush, on Indigenous Land or the traditional territory of the Fort William First Nation, signatories of the 1850 RobinsonSuperior Treaty. The close access and re-connection with the Land was powerful for these northern Nishnawbe youth who had grown up in the bush with daily contact on the Land but who now felt confined or imprisoned by the school and city limits of streets, concrete, and pavement.

\section{Raising the Strengths and Capacities of Indigenous Youth Civic Engagement}

Rather than remain caught in a cycle of social oppression, marginalization, and settler-colonialism (Tuck \& Gaztambide-Fernandez, 2013) through mainstream schooling, pedagogy and curriculum, the Tikkun Indigenous Youth Land-based retreat provided the supports, well-being strategies, and opportunities for Indigenous youth to reclaim autonomy and build capacity for their own cultural community/civic engagement. Youth were involved in games, team initiatives, culturally responsive activities, and Laughter Yoga sessions to engage in non-verbal communication, build a youth collectivity of greater trust and relationships, develop leadership skills through collaboration, connect to cultural practices and the Land, and experience embodied healing through role-plays and Laughter Yoga.

Assisting youth with activities and well-being strategies that they can then use in real life after the Tikkun research was "completed" was an important capacity-building goal of the project. Capacity-building through the retreat

177 | The Tikkun Indigenous Youth Project 
activities was light, fun, and informal in approach while simultaneously having a serious impact on the high school's Indigenous youth culture. The retreat activities gave the Indigenous youth embodied opportunities to be actively involved in positive relationship-building with their peers which then translated into their own civic engagement. Fun, low-stakes activities such as the back-pocket games encouraged the Indigenous youth to feel comfortable enough to start their own games and conversations with one another while other activities were designed to challenge them to work and problem-solve together to achieve a common goal. Sharing circles were culturally relevant processing methods for students to cope in a positive way as well as "ease tension or anxiety" that may have come up. Laughter yoga again was a way for students to be actively involved and try a positive coping strategy. These are foundational blocks or essential skills for community (civic) engagement education. In our Tikkun Indigenous Youth Project, the youth were more than able to demonstrate their increased awareness for action, improve their own social justice discourse, gain tools and methods to help each other reflect, echo, and collaborate on a collective vision, and gather strength and resolve for greater Indigenous resurgence, sovereignty, and traditional/treaty rights in their communities.

\section{Indigenous-determined Community/Civic Engagement is Good for Everyone}

Inside the context of mainstream education, it is critical to engage all youth in a model of Indigenist or indigenized civic engagement education because it is a holistic, relational, and respectful youth-driven approach to democratic practices and community adhesion. When the Indigenous youth were given the opportunity to choose and take the lead for the games and initiatives during the retreat, the engagement and capacity to participate for all youth was exponentially increased and deeply experienced on multiple dimensions. The mentorship model with a supportive mentee empowered the four Nishnawbe youth leaders to reclaim self-determination and in turn, become role-models for their Indigenous peers' capacity for civic engagement.

Indigenized or Indigenist civic engagement education is first focused on Indigenous youth self-determination for democratic participation in their 
own communities and education. When we centered the Tikkun research on what "engaged citizenship" means for Indigenous youth, who are routinely denied the rights and opportunities afforded to settler youth in civic engagement education, we discovered that the Indigenous youth knew what they needed and how it promoted skills and capacity lacking in mainstream non-Indigenous youth populations. When Indigenous youth were in a position to determine what citizenship and civic engagement means to them and their communities, they grew in capacity to reclaim autonomy in decision-making, well-being of mind and body, strength of voice, cultural identity, and the ability to envision a positive collective future.

We were convinced that providing a more Indigenist, respectful, and safe space for cultural and personal self-expression in schools would help combat or reduce the negative micro/macro aggressions of settler-colonialism that hurts all Canadians, especially Indigenous youth. When we can engage in an Indigenist model of community/civic engagement by acknowledging, encouraging, and affirming Indigenous knowledge systems, cultural protocols, and holistic models, we can all better participate democratically and contribute to community well-being - a model of civic engagement that is good for all Indigenous and Canadian citizens to share their own cultural values, beliefs, traditions, teachings, etc.

\section{Tips for Organizing Tikkun Youth-led Retreats}

The Tikkun Indigenous Youth Land-based retreat as a culminating activity of the 3-year research project allowed the research team to fulfill and extend the four objectives outlined by the global Tikkun Youth Project, as well as go beyond the original intended purposes of the well-being retreat for northern Indigenous youth seeking an education in the city. Our retreat goals included building positive healing relationships amongst all participants involved, providing a safe-space for the youth leaders to develop a voice for selfadvocacy, empowering youth to become leaders and agents of change, and providing a safe-space for healing where youth were able to build their confidence, pride, community, and relationships amongst themselves.

Based on the successful experience of the Tikkun Indigenous Youth Landbased well-being retreat, we have provided the following guidelines and recommendations that should be considered when designing and 
implementing a program committed to the well-being of Indigenous youth for collective strength, resurgence of cultural ways of knowing, and indigenized civic engagement by youth, with youth. First, conduct Landbased activities or a retreat at an outdoor centre that gives full unfettered access to the Land. Being outside and connecting to the Land is the most ideal setting because it often reminds youth of home in their northern communities. This Land-based setting should be a safe space for Indigenous youth to freely interact with other Indigenous youth and should be a minimum of two nights and three days for greater immersion in an Indigenous-focused environment. We found that this allowed time for the youth to become comfortable with themselves, their environment, their peers, and others who were present.

Second, implement a mentorship process to encourage as much youthled activities as possible. Youth should have the opportunity to be part of the planning process. This gives youth a voice and can be extremely empowering for themselves and their peers. Third, include icebreaker games at the beginning of the retreat to encourage playful interactions. These lowstake games help youth become comfortable with one another and their environment. Fourth, include youth-led team initiatives. These initiatives help support and empower all youth who are involved. Fifth, invite guest speakers (i.e., First Nation community leaders and Elders) who promote culturally relevant activities and teachings specific to the group. Sixth, include sharing circles as part of the evening ritual to give youth a chance to share stories and to express their opinions, views, and experiences. This is an important time for youth to be heard and respected. Seventh, include an embodied activity that allows youth the chance to interact and laugh with each other. Laughter Yoga is a great option; however, it may not be available. Another example of an embodied activity is a youth-led comedy show. Lastly, create a communication strategy to gain the support of educators, school administrators, and organizations who work with First Nation youth to make the retreat possible. Schools, organizations, and parents/guardians need to see the value of the program. 


\section{Conclusion}

We began this chapter by summarizing the research observations of Lakehead University's Tikkun Indigenous Youth Project from Years 1 and 2 of the educational inequities that continue to impact Nishnawbe youth in the northern Ontario city of Thunder Bay. The ongoing colonial impacts of Canada's education policies continue to degrade the overall well-being of Indigenous youth, as tragically demonstrated by the deaths of the seven Nishnawbe youths (the Seven Fallen Feathers), resulting in Ontario's longest coroner's inquest to understand the dangers and risks involved when northern Nishnawbe students attempt to access to their treaty and human right to a high school education. This was the context of the third year of the Indigenous Tikkun Youth Project's research into youth civic engagement. We decided that the research project needed to offer and demonstrate an alternative to settler-colonial conditions of civic education; hence, we aimed to design and engage the Indigenous youth in an alternative threeday educational experience that focused on Indigenous self-determination, resurgence, cultural strengths, and collective well-being. We focused on an incremental youth mentorship process for leadership and capacity-building for Nishnawbe youth to decide and engage in healing with, by, and for their Indigenous peers.

Indigenous youth civic engagement in Canadian education or Ontario curriculum has mostly been ignored, avoided, or fraught with ongoing obstacles and barriers of settler-colonialism, institutionalized racism, and curricula that does not recognize the vital contributions of Indigenous peoples in contemporary Canadian society. In our Tikkun Indigenous youth research, we focused on how northern Nishnawbe youth face ongoing dangers, risks, and challenges when trying to access their basic right to a high school education, not only due to historic treaties but also as the First Peoples of Canada and a citizen of one of the richest countries and most successful education systems in the world.

The focus of this retreat was to assist Indigenous youth in finding different ways and methods to reclaim their collective strength, self-determination, and critical autonomy within education as an institution, as well as in urban school spaces that continue to subject Indigenous youth to oppression, racism, erasure, and silence on a regular basis. Our first goal with the Landbased well-being weekend was to interrupt those systemic oppressive forces 
in a type of retreat or time-out, away from the city, the urban high school, the students' boarding homes, and mainstream colonial expectations and routines. We created a time, place, and context for Indigenous youth to be able to commit to themselves, to focus on their own well-being, to connect to a community or peers for a bonding or collective experience where the activities, conversations, and experiences were designed and determined by Indigenous youth, for Indigenous youth, and with Indigenous youth.

From this 3-day Land-based retreat, we were able to observe and document a variety of positive findings that are promising for improving the agenda of civic engagement education research to teach culturally safe, community positive, and experiential collective strength by/with Indigenous youth as active participants who are in control of their own learning and community-building. We learned that personal-collective connections and safe-positive relationships with their Indigenous peers were vitally important for Indigenous youth to be able to talk about their cultural hopes and socially-just futures, as well as what they can accomplish with civic engagement in their communities. The culminating retreat of the Indigenous Tikkun Youth Project was a break with the constant tide of settlercolonialism in urban schools where youth continue to experience cultural erasure and are forced into a deficit perception of their Indigenous identity and community membership while school, curricula, and institutional supports are lacking, missing, or unfulfilled.

Finally, our greatest hope for the value of the Tikkun Indigenous Youth Project was realized when one Indigenous youth participant beautifully articulated their understanding of the retreat's purpose: "I felt like this thing [retreat] was pointless at first ... I felt like we were just a bunch of Indians ... coming here to chill ... until we started doing activities and then I started seeing why we were coming here ... to learn and gain experiences together. To try and build a better future for all of us by opening our eyes and seeing different possible things" (Cabin 4, 43:10). 


\section{Appendix}
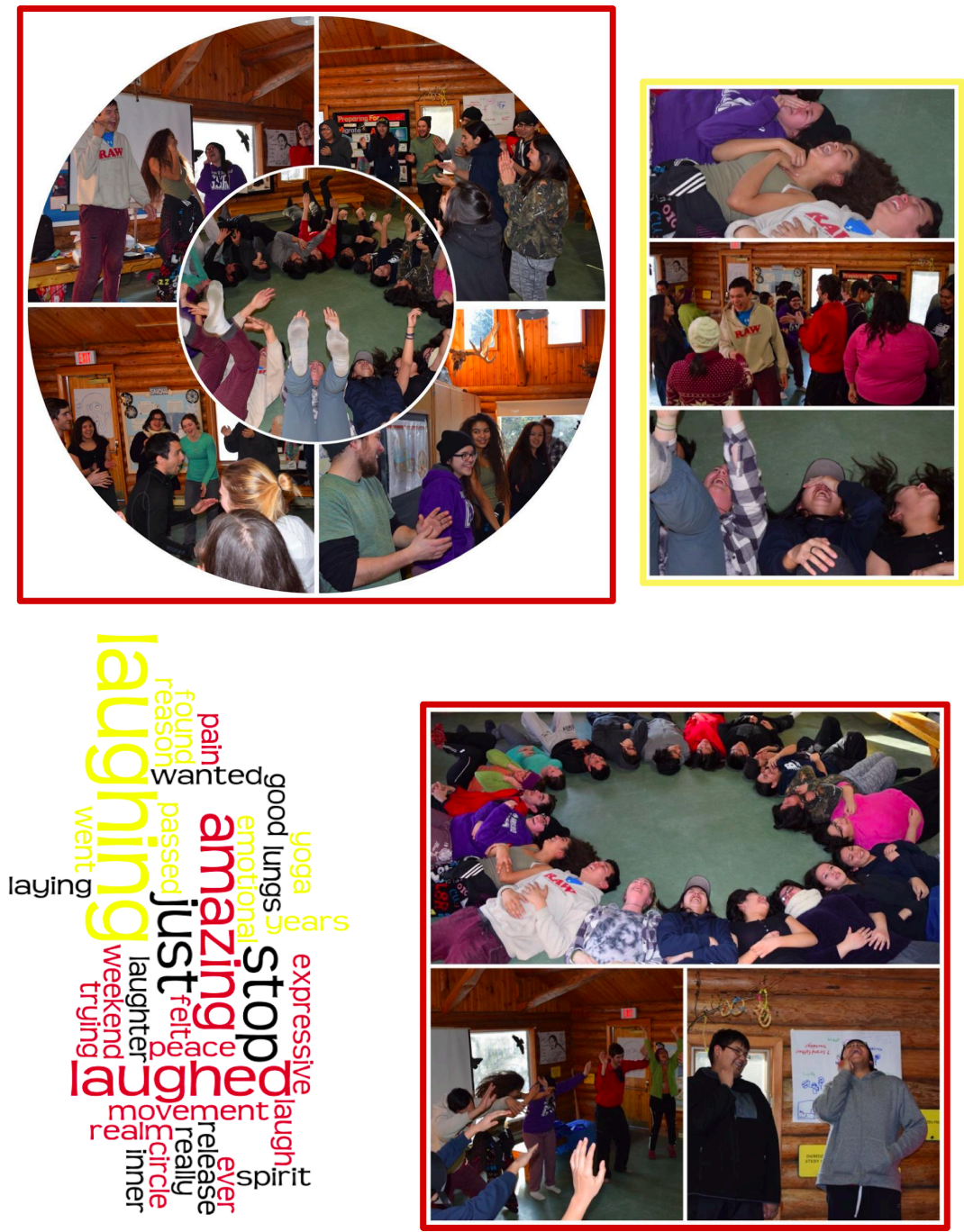

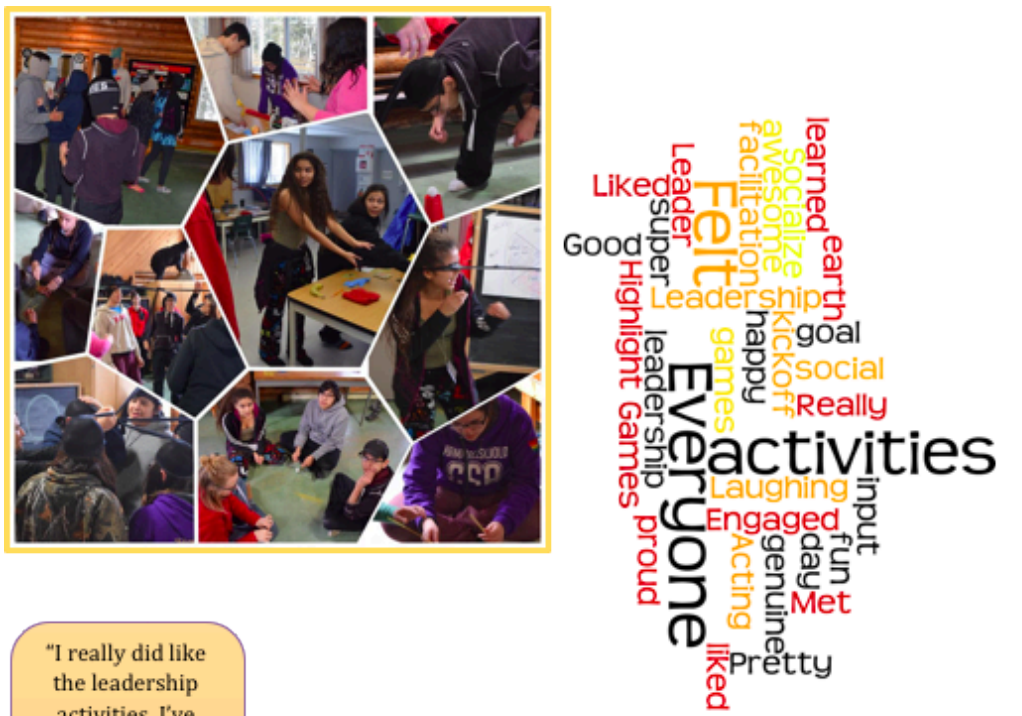

"I really did like the leadership activities. I've done a lot of leadership things but I've never actually put my input in cause I was shy, but I kinda know you guys better so it was easier...it was nice to get people I see everyday at school...and actually get to talk to them. If I was at school I'd

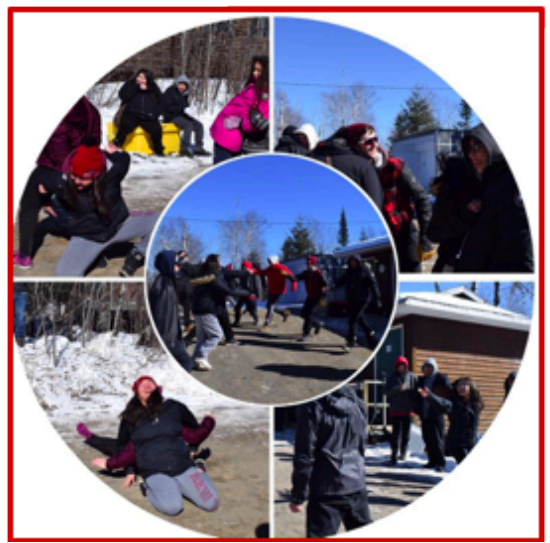




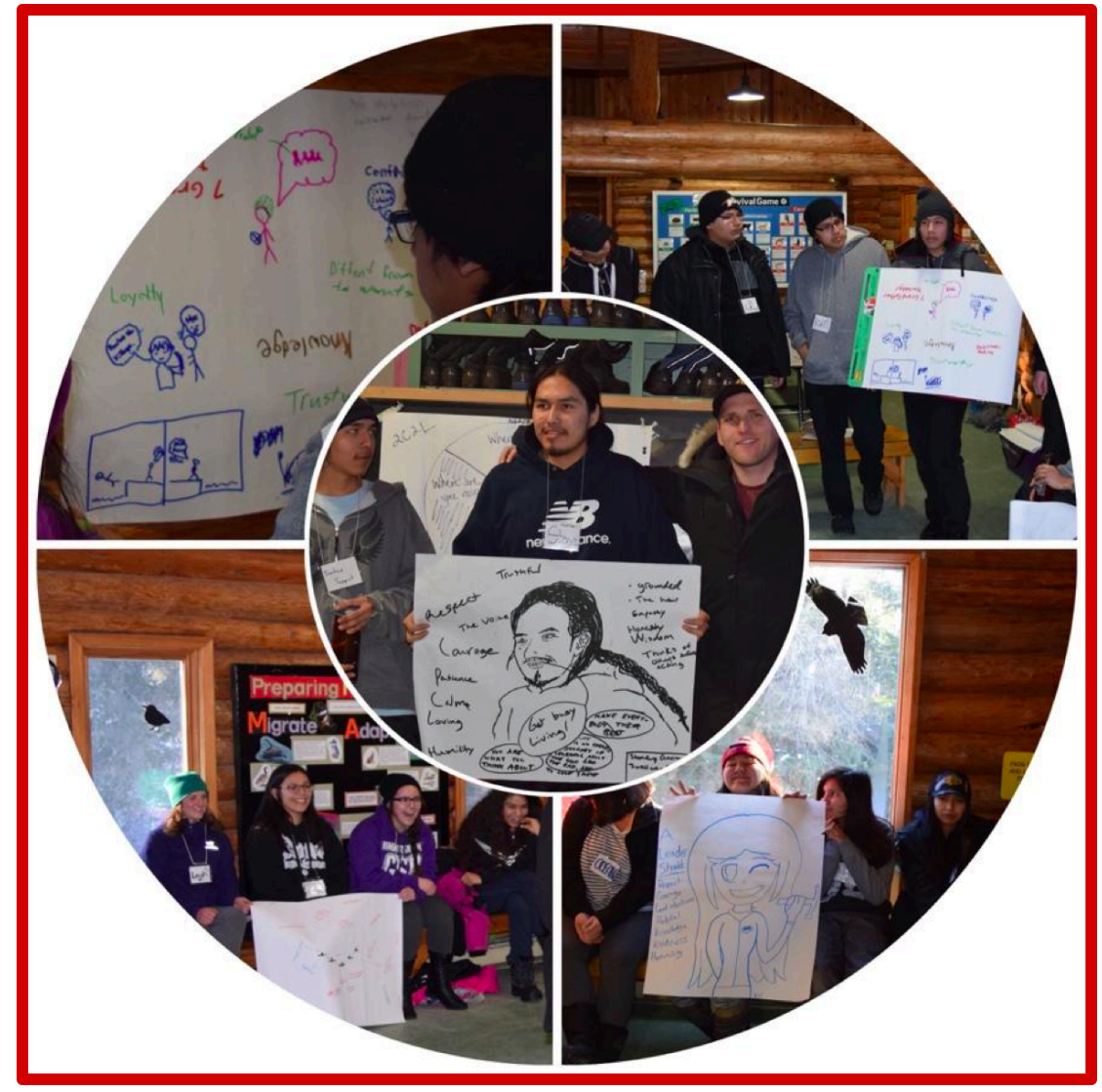

185 | The Tikkun Indigenous Youth Project 


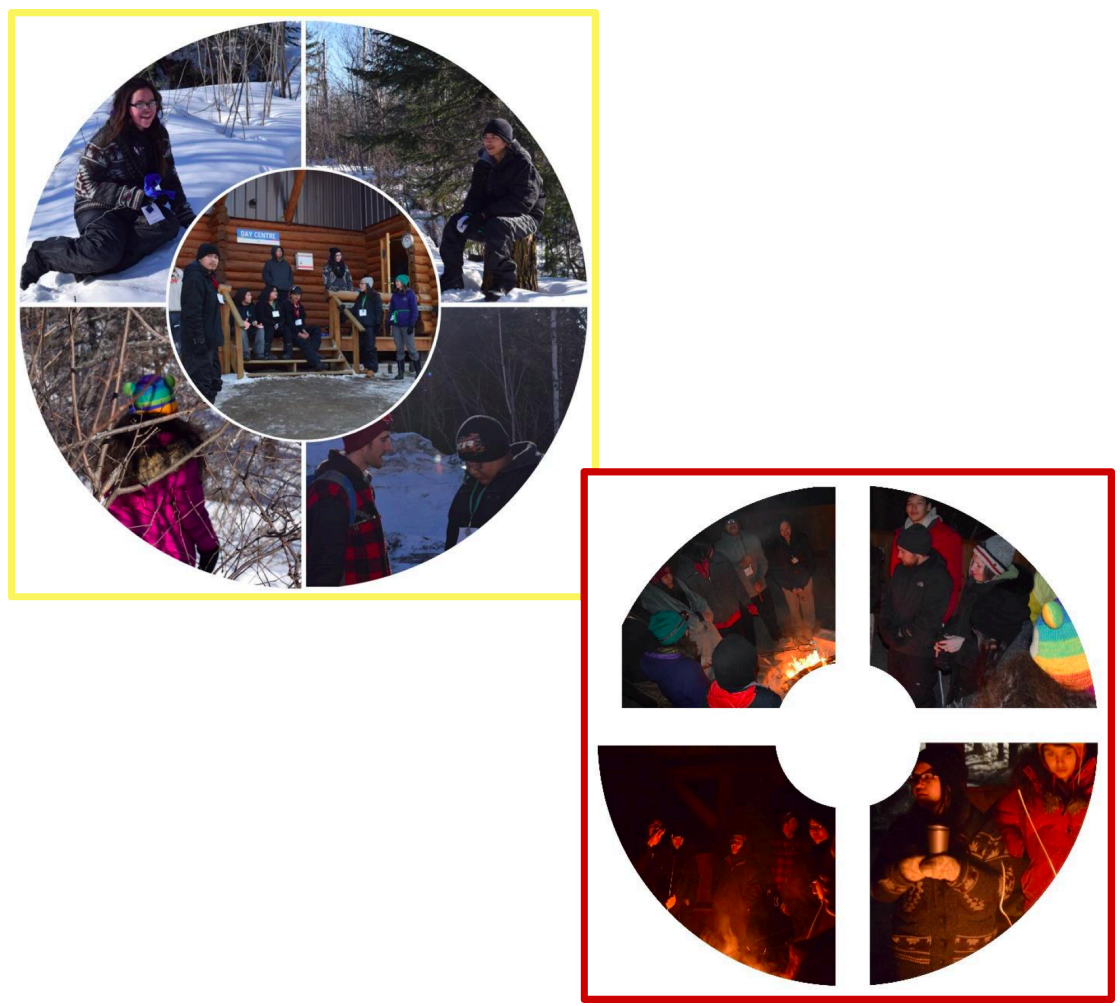

\section{References}

Battiste, M. (2004). Unfolding the lessons of colonization. In C. Sugars (Ed.), Unhomely states: Theorizing English-Canadian postcolonialism (pp. 209-220). Peterborough, ON: Broadview Press.

Castellano, M. B. (2006). Final report of the Aboriginal Healing Foundation:

Volume 1. Ottawa, ON: Aboriginal Healing Foundation.

Cooke, C. (2018, June 22). Metis doctor honoured for serving remote Indigenous communities. The Current. Retrieved from http://www.cbc.ca/radio/thecurrent/m-tis-doctor-honoured-forserving-remote-indigenous-communities-1.4717710

First Nations Health Authority. (2015). Hope, help, and healing. A planning toolkit for First Nations and Aboriginal communities to prevent and 
respond to suicide. Retrieved from http://www.fnha.ca/wellness/ wellness-for-first-nations/mental-wellness-and-substance-use

First Nations Information Governance Centre. (2014). Youth resilience and protective factors associated with suicide in First Nations communities. Ottawa, ON: First Nations Information Governance Centre.

Gardam, K., \& Giles, A. R. (2016). Media representations of policies concerning education access and their roles in seven First Nation students' deaths in northern Ontario. The International Indigenous Policy Journal, 7(1). doi:10.18584/iipj.2016.7.1.1

Grande, S. (2008). Red pedagogy: The un-methodology. In N. K. Denzin, Y. S. Lincoln, \& L. T. Smith (Eds.), Handbook of critical and Indigenous methodologies (pp. 233-254). Thousand Oaks, CA: SAGE.

Hare, J., \& Pidgeon, M. (2011). The way of the warrior: Indigenous youth navigating the challenges of schooling. Canadian Journal of Education/ Revue Canadienne De Léducation, 34(2), 93-111. Retrieved from http://www.jstor.org/stable/pdf/canajeducrevucan.34.2.93.pdf

Korteweg, L., \& Bissell, A. (2016). The complexities of researching youth civic engagement in Canada with/by Indigenous youth: Settler-colonial challenges for Tikkun Olam pedagogies of repair and reconciliation. Citizenship Education Research Journal/Revue de recherche sur l'éducation à la citoyenneté, 5(1), 14-26. Retrieved from http://ejournals.ok.ubc.ca/ index.php/CERJ/article/view/14

Korteweg, L., \& Fiddler, T. (2018). Unlearning colonial identities while engaging in relationality: Settler teachers' education-as-reconciliation. McGill Journal ofEducation/Revue des sciences de l'éducation de McGill, 53(2). doi:10.7202/1058397ar

Macdonald, N. (2017, July 7). A river of tears. Maclean's. Retrieved from www.macleans.ca/river-of-tears/

Neeganagwedgin, E. (2013). A critical review of Aboriginal education in Canada: Eurocentric dominance impact and everyday denial. International Journal of Inclusive Education, (17)1, 15-31. doi:10.1080/13603116.2011.580461

Provincial Advocate for Children and Youth (Ontario). (2014). Together we are ... Feathers of hope report: A First Nations youth action plan. Toronto, ON. Retrieved from http://cwrp.ca/sites/default/files/publications/en/ Feathers of Hope.pdf

Richards, J. (2014). Are we making progress? New evidence on Aboriginal education outcomes in provincial and reserve schools. Toronto, ON: C. D. Howe Institute. 
Sinclair, M. (2015). Justice Murray Sinclair's remarks on the Truth and Reconciliation Reports. Maclean's. Retrieved from https://www.macleans.ca/news/canada/justice-murray-sinclairsremarks-on-the-truth-and-reconciliation-report/

Styres, S. (2011). Land as first teacher: A philosophical journeying. Reflective Practice: International and Multidisciplinary Perspectives, 12(6), 717-731. doi:10.1080/14623943.2011.601083

Talaga, T. (2017). Seven fallen feathers: Racism, death, and hard truths in a northern city. Toronto, ON: House of Anansi Press Inc.

Talaga, T. (2018). All our relations: Finding the path forward. CBC Massey Lectures. Toronto, ON: House of Anansi Press Inc.

Tuck, E. (2011). Humiliating ironies and dangerous dignities: A dialectic of school pushout. International Journal of Qualitative Studies in Education, 24(7), 817-827. doi:10.1080/09518398.2011.632785

Tuck, E., \& Gaztambide-Fernández, R. A. (2013). Curriculum, replacement, and settler futurity. Journal of Curriculum Theorizing, 29(1), 72-89. Retrieved from http://journal.jctonline.org/index.php/jct/article/view/ $411 / \mathrm{pdf}$

1 "Land" is capitalized (Styres, 2011) to indicate its complexity as a knowledge source and where the elements, ancestors, more-than-human animals, spirits, language, and stories are all interconnected with Indigenous peoples over millennia or time, immemorial as a system of relations and knowledge that continues living to this day.

2 "Nishnawbe" refers specifically to the youth who are part of the Nishnawbe Aski Nation (NAN) and are Ojibwe or Oji-Cree. Throughout this chapter, Nishnawbe and First Nations are used interchangeably.

$\underline{3}$ In this chapter, we use the terms Indigenous and First Nations, Métis, and Inuit (FNMI) to refer to Indigenous youth as a group of peoples.

4 The term "northern" refers to students/youth who hail from distant, rural, or remote First Nations communities north of Thunder Bay and who are most often in boarding homes with parents and other family members at a great distance. 